\title{
Peran Iptekin dalam Mengatasi COVID-19: Pembelajaran dari Beberapa Negara
}

\author{
Hammam Riza \\ Kepala \\ Badan Pengkajian dan \\ Penerapan Teknologi (BPPT) \\ Jakarta, Indonesia \\ hammam.riza@bppt.go.id
}

\author{
Iwan Sudrajat \\ Pusat Teknologi Kawasan \\ Spesifik \& Sistem Inovasi \\ Badan Pengkajian dan \\ Penerapan Teknologi (BPPT) \\ Jakarta, Indonesia \\ iwan.sudrajat@bppt.go.id
}

\author{
Fathoni Moehtadi \\ Pusat Teknologi Kawasan \\ Spesifik \& Sistem Inovasi \\ Badan Pengkajian dan \\ Penerapan Teknologi (BPPT) \\ Jakarta, Indonesia \\ fathoni.moehtadi@bppt.go.id \\ Lambas P. Panggabean \\ Pusat Teknologi Kawasan \\ Spesifik \& Sistem Inovasi \\ Badan Pengkajian dan \\ Penerapan Teknologi (BPPT) \\ Jakarta, Indonesia \\ lambas.parlaungan@bppt.go.id
}

\begin{abstract}
Corona Virus Desease (COVID-19) pertama kali dilaporkan di Wuhan pada Desember 2019. Kemudian menyebar ke berbagai bagian Tiongkok, dan secara bertahap menjadi pandemi global pada Maret 2020. Sementara jumlah kematian terus meningkat, besaran korban telah bergeser dari Asia ke Eropa, dan ke Amerika Serikat (AS). Makalah ini menganalisis respon di negara-negara Tiongkok, Korea Selatan (Korsel), Italia, dan AS, dan memberikan gambaran bagaimana pemanfaatan Artificial Intelligence (AI) dan Big Data. Sementara negara-negara ini memiliki mekanisme tata kelola yang berbeda, ditemukan bahwa beberapa kebijakan penerapan iptekin AI dan Big Data di masing-masing negara memiliki kekhasan. Pandemi memang bersifat global, namun respon masing-masing negara sangat tergantung pada kondisi lokal. Mengingat respon terhadap penyebaran infeksi COVID-19 tersebut tergantung pada kepentingan dan urgensinya, penerapan AI dan Big Data di Tiongkok, Korsel, dan Italia mempunyai kesamaan. Negara-negara ini cenderung menerapkan AI dan Big Data lebih pada strategi pelandaian kurva sementara AS lebih cenderung menerapkan strategi peningkatan kemampuan pelayanan kesehatan.
\end{abstract}

Keywords-peran teknologi, COVID-19, strategi pelandaian kurva, strategi peningkatan kemampuan pelayanan kesehatan, AI, big data

\section{Pendahuluan}

\section{A. Latar Belakang}

Sejak merebaknya COVID-19 ke berbagai penjuru dunia telah membuat lebih dari 210 negara mengerahkan segenap daya dan kebijakan untuk penanggulangan dan pencegahan. Negara dengan kemampuan dan antisipasi tinggi dengan sigap melakukan berbagai upaya dan kebijakan untuk mengantisipasi sebelum virus corona hadir di negaranya. Namun, negara lain mempunyai respon yang menengah dan bahkan lambat, sehingga mengalami kesulitan yang besar karena sifat penjangkitan COVID-19 yang luar biasa cepat. Kecepatan merebaknya corona kurang diimbangi dengan kecepatan tindakan penanggulangannya.

Kajian terhadap beberapa negara yang mengalami serangan COVID-19 mempunyai tingkat perkembangan yang berbeda-beda. Di negara asal mula merebaknya COVID-19, China, dari kajian sebelumnya diketahui mengalami kecepatan yang tinggi ketika merebak, namun kecepatan melandainya juga cepat. Kurang lebih hampir serupa, Korsel juga mengalami sebentar, kemudian melandai. Sementara Amerika Serikat mengalami masa parah yang panjang, bahkan hingga Mei 2020 terutama di episenternya, Negara Bagian New York. Sedangkan Italia walaupun mengalami tingkat yang cukup parah, hingga memuncak kemudian mulai melandai [1]. 
Keberhasilan negara-negara di dalam memerangi COVID-19 jika diamati dengan seksama tampaknya terkait erat dengan kebijakan Pemerintah yang tepat, diikuti dengan tingkat kepatuhan masyarakat, dan peran ilmu pengetahuan, teknologi dan inovasi (iptekin) yang mendukungnya. Pada saat semua orang membutuhkan informasi yang lebih baik, termasuk pemodel penyakit epidemi, pejabat publik, organisasi internasional dan orang-orang di karantina atau yang menjaga jarak sosial (social distancing), informasi digital dan teknologi pengendalian telah dikerahkan dengan cara yang belum pernah terjadi sebelumnya untuk mengumpulkan data dan bukti yang dapat diandalkan guna mendukung pengambilan kebijakan kesehatan masyarakat.

Tulisan ini mencoba mengkaji peran Iptekin di dalam melawan COVID-19 di negara-negara Korsel, Tiongkok, Italia dan AS.Pengertian Iptekin di sini adalah terutama (tapi tidak terbatas kepada) Pemanfaatan Artificial Inteligence (AI)dan Big Data.

\section{B. Tujuan}

Tulisan ini bertujuan untuk memperoleh pemahaman mengenai penerapan kebijakan iptekin dalam mengatasi COVID-19 di beberapa negara:

1. Mengetahui upaya penerapan iptekinapa saja yang telah dilakukan suatu Negara/Epicenter dalam menghadapi pandemi COVID-19.

2. Memperoleh analisis efektivitas kebijakan pemanfaatan iptekin dalam melandaikan kurva COVID-19

\section{Metodologi Pendekatan}

Metode yang digunakan untuk penyusunan kajian adalah desk study. Dalam desk study seluruh tahapan dilakukan dengan menggunakan data sekunder yang dikumpulkan dari sejumlah dokumen baik berupa laporan, data statistik, buku, jurnal hingga berita yang diterbitkan oleh situs/media terpercaya. Metode pengumpulan data dilakukan umumnya melalui mesin pencari di internet. Oleh karena itu diperlukan kejelian untuk memilih dan mengunduh sumber guna menjamin keakuratan data yang digunakan.

Kajian ini dilakukan dengan beberapa tahapan hingga menghasilkan kesimpulan dan pembelajaran. Data yang dikumpulkan untuk menjawab tujuan kajian yaitu mengetahui langkah Pemerintah di empat negara yakni Tiongkok, Korsel, Italia dan AS dalam menanggulangi pandemi COVID-19. Beberapa data yang penting untuk mendukung tujuan tersebut adalah (a) data kasus, berupa jumlah dan dinamika yang terjadi pada setiap negara (b) penambahan jumlah kasus per hari, total kematian, kematian per hari. Kemudian data diidentifikasi dan dianalisis dengan diawali pengenalan karakteristik tiap kasus yang terjadi yang kemudian diintegrasikan dengan kebijakan yang muncul akibat kasus tersebut. Kemunculan kebijakan tersebut dapat dipercepat dalam pencapaiannya dengan dukungan dari masyarakat dan dukungan iptekin. Oleh karena itu penting untuk mengetahui peran dari keduanya.

\section{KeRANGKA TeORI}

Pengambilan kebijakan yang cepat dan tepat adalah kunci untuk memerangi COVID-19. Pengalaman Tiongkok memperkuat pentingnya mendengarkan sains dan pakar kesehatan masyarakat selama peristiwa pandemi. Dan bereaksi berlebihan lebih baik daripada tidak bereaksi. Manajemen risiko sistematis dan proaktif Tiongkok yang belum pernah terjadi sebelumnya, berdasarkan kolaborasi antara pejabat pemerintah dan pakar kesehatan.Rilis data klinis terkait penyakit yang tepat waktu kepada publik dan WHO membantu banyak orang di seluruh dunia mempersiapkan penyebaran. Sebagai contoh, menganalisis lebih dari 40.000 kasus di Cina, $80 \%$ pasien yang terinfeksi COVID-19 tidak memerlukan intervensi medis, sementara 20\% membutuhkan perawatan dan perawatan medis. Provinsi Zhejiang adalah yang pertama meningkatkan respons manajemen risiko ke tingkat tertinggi pada hari-hari awal wabah, ketika tidak ada kasus yang dikonfirmasi [2].

Kritikos[3], di dalam tulisannya Ten technologies to fight coronavirus telah meyakinkan bahwa begitu COVID-19 berkembang, aplikasi teknologi dan prakarsa telah berlipat-ganda dalam upaya untuk menghentikan merebaknya penyakit, mengancam pasien dan membuat tekanan pekerja-pekerja pelayanan kesehatan yang bekerja sangat keras, sambil mengembangkan vaksin-vaksin baru yang efektif [3]. 
Selanjutnya dikatakan, bahwa kecerdasan buatan, robot, dan drone sedang dikerahkan untuk membantu melacak penyakit dan menegakkan tindakan pembatasan; sementara para ilmuwan dengan panik menerapkan pengeditan gen, biologi sintetik dan teknologi nano dalam upaya untuk mempersiapkan dan menguji vaksin, perawatan, dan diagnostik masa depan. Aplikasi Blockchain dapat melacak penularan, mengelola pembayaran asuransi, dan menegakkan rantai pasokan medis. Lebih lanjut, teknologi cetak 3D dan Open Source nampaknya mampu menopang upaya pemerintah dan rumah sakit di seluruh dunia untuk memenuhi meningkatnya kebutuhan akan perangkat keras medis (misalnya masker wajah, Ventilator dan Filter Pernapasan) dan mengoptimalkan pasokan peralatan medis yang diperlukan. Pada saat yang sama, teknologi telehealth menawarkan cara yang hemat biaya untuk memperlambat penyebaran virus dan mempertahankan kapasitas rumah sakit dengan mengoperasikannya sebagai filter yang memungkinkan, menjaga mereka yang memiliki gejala sedang di rumah dan membawa kasus yang lebih parah ke rumah sakit.

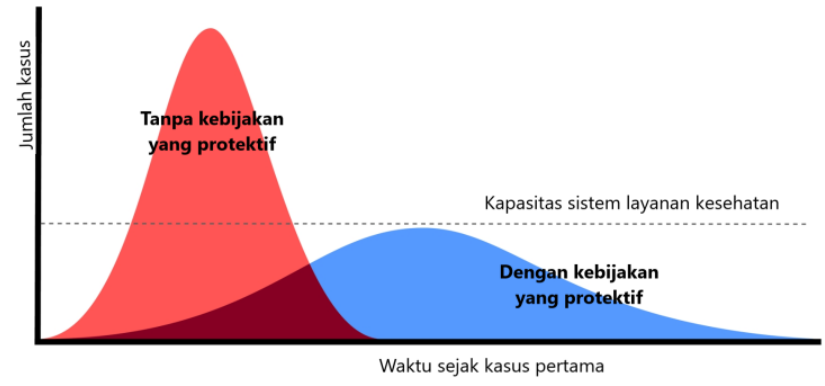

Gambar 1. Kurva yang melandai/merata menunjukkan penurunan tingkat infeksi virus corona dapat mengurangi dampak negatif terhadap sistem layanan kesehatan.(adaptasi dari CDC [4])

Sejalan dengan terus berkembangnya pandemi, negara-negara juga menambah jenis teknologi yang diterapkan untuk mendukung Strategi Pelandaian Kurva (Flattening Curve Strategy) pada saat itu [5]. Dengan terus bertambahnya jumlah total kasus terinfeksi COVID-19, maka strategi berikutnya, yakni Strategi Peningkatan Kemampuan Perawatan Kesehatan (Raising the Health Care Capacity Strategy) mulai diimplementasikan, dan teknologi-AI dan Big Data yang dapat mendukungnya juga diterapkan [6].

\section{Hasil KaJian dan Analisis Penerapan Strategi IPTEKIN di NEGARA-NEGARA: TiONGKOK, KOREA SELATAN (KORSEL), ITALIA, DAN AMERIKa Serikat (AS)}

\section{A. Penerapan Strategi Mengatasi COVID-19}

Untuk mengatasi masalah penanganan penyebaran COVID-19 negara-negara Tiongkok, Korsel, Italia, dan AS juga mengambil kebijakan menerapkan Strategi Pelandaian Kurva dan Strategi Peningkatan Kemampuan Pelayanan Kesehatan. Untuk melihat latar belakang pengambilan kebijakan yang diambil negara-negara tersebut, maka dalam bagian ini, akan dilihat dua (2) grafik, yaitu Grafik Jumlah Penambahan Kasus Positif COVID-19 per harinya dan Grafik Kumulatif Total Kasus, untuk masing-masingnegara, Tiongkok, Korsel, Italia, dan AS.

Apabila diteliti pola grafik masing-masing negara tersebut maka dari data yang terkumpul untuk Tiongkok, Korea, Italia dan AS dapat diperoleh pemahaman sebagai berikut. Data Pola Grafik untuk Negara-negara Tiongkok, Korsel, Italia dan AS adalah sebagai dapat dilihat pada tabel berikut. 
Tabel 1. Data Pola Grafik Negara-negara Tiongkok, Korsel, Italia dan AS. Data diolah, 2020 [1].

\begin{tabular}{|c|c|c|c|c|c|c|c|c|c|}
\hline \multirow[b]{2}{*}{ NO } & \multirow[b]{2}{*}{ NAMA GRAFIK } & \multicolumn{2}{|c|}{ TIONGKOK } & \multicolumn{2}{|c|}{ KOREA } & \multicolumn{2}{|c|}{ ITALIA } & \multicolumn{2}{|c|}{ AS } \\
\hline & & NO GRAFIK & POLA GRAFIK & NO GRAFIK & POLA GRAFIK & NO GRAFIK & POLA GRAFIK & NO GRAFIK & POLA GRAFIK \\
\hline 1 & $\begin{array}{l}\text { GRAFIK JUMLAH PENAMBAHAN } \\
\text { KASUS POSITIF COVID19 PER HARI }\end{array}$ & GAMBAR A-2 & MENURUN & GAMBAR B-3 & MENURUN & GAMBAR C-2 & $\begin{array}{l}\text { CENDERUNG } \\
\text { MENURUN }\end{array}$ & GAMBAR D-2 & $\begin{array}{l}\text { CENDERUNG } \\
\text { MENURUN }\end{array}$ \\
\hline 2 & $\begin{array}{l}\text { GRAFIK KUMULATIF TOTAL KASUS } \\
\text { POSITIF COVID19 PER HARI }\end{array}$ & GAMBAR A-3 & $\begin{array}{l}\text { CENDERUNG } \\
\text { MENAIK }\end{array}$ & GAMBAR B-3 & $\begin{array}{l}\text { CENDERUNG } \\
\text { MENAIK }\end{array}$ & GAMBAR C-3 & MENAIK & GAMBAR D-4 & MENAIK \\
\hline
\end{tabular}

Terlihat bahwa pada keempat negara, baik untuk Grafik Jumlah Penambahan Kasus Positif COVID-19 per hari, maupun untuk Grafik Kumulatif Total Kasus Positif COVID-19 per hari, pola grafiknya menunjukkan hampir sama.Untuk Grafik Jumlah Penambahan Kasus Positif COVID-19 per hari, keempat negara menunjukkan pola menurun. Di Tiongkok dan Korsel polanya konsisten menurun, sedangkan Italia dan AS secara umum dapat dikatakan cenderung menurun.Untuk Grafik Kumulatif Total Kasus Positif COVID-19 per hari, keempat negara menunjukkan pola meningkat. Walaupun Tiongkok dan Korsel polanya secara umum cenderung menurun, sedangkan Italia dan AS secara umum dapat dikatakan konsisten menurun.

Dengan pola grafik di negara Tiongkok, Korsel, Italia dan AS seperti yang ditunjukkan di atas maka dapat dikatakan bahwa upaya Containment dan Mitigation, misalnyasocial distancing, stay at home dan sebagainya, telah berhasil mengurangi pertambahan kasus terinfeksi per harinya. Dengan demikian dapat dikatakan bahwa Strategi Pelandaian Kurva sudah berhasil. Namun sebaliknya, upaya terkait Peningkatan Kemampuan Pelayanan Kesehatan masih perlu ditingkatkan.Ini terlihat dari kenyataan bahwa pertambahan Jumlah Total Kasus Terinfeksi COVID-19 yang masih cenderung meningkat. Agar hasil-hasilnya lebih efektif, maka pemanfaatan AI harus lebih banyak diarahkan kepada Peningkatan Kemampuan Pelayanan Kesehatan. Demikian juga kebijakan terkait pemanfaatan AI, sebaiknya diarahkan untuk mendukung Strategi Peningkatan Kemampuan Pelayanan Kesehatan.

\section{B. Tahapan Pengembangan IPTEKIN}

Selain meneliti kondisi penerapan strategi melawan Pandemi COVID-19 di Tiongkok, Korsel, Italia dan AS, seperti yang telah dibahas diatas, pada bagian ini, kondisi jenis teknologi yang dipergunakan untuk mendukung salah satu strategi melawan COVID-19 akan dibahas.

AI dan Big Data dapat mendukung fungsi-fungsi yang berguna untuk mengenali, mendiagnosis, memprediksi, dan menjelaskan terjadinya infeksi COVID-19. Selain itu, AI dan Big Data juga dapat mendukung pelaksanaan pengelolaan dampak sosial ekonomi [7].

Data Jenis AI dan Big Data yang digunakan untuk mendukung salah satu strategi melawan COVID-19 kemudian diidentifikasi dan dihimpun dengan meneliti praktek dan pelaksanaan pada tiap negara yang dikaji. Untuk itu, data tentang Strategi Pelandaian Kurva (Flattening the Curve Strategy)dan Strategi Peningkatan Kapasitas Perawatan Kesehatan (Raising the Health Care Capacity Strategy)di Tiongkok, Korsel, Italia dan AS, dikumpulkan. Data jenis-jenis teknologi yang diterapkan di negara-negara tersebut diklasifikasikan kedalam kategoriResearch (R), Development \& Engineering (DE), Available (A) dan Operational (O). Selain melakukan klasifikasi R, DE, A dan O, maka data jenis teknologi yang diterapkan di negara-negara Italia, AS, Tiongkok dan Korsel juga diklasifikasikan ke dalam jenis-jenis strategi dalam melawan pandemi COVID-19 di mana jenis teknologi AI dan Big Data tersebut diterapkan.

Menurut Naudé (2020) terdapat enam (6) upaya dimana AI dan Big Data dapat berkontribusi dalam melawan pandemi COVID-19. Keenam teknologi tersebut tiga di antaranya dapat dimasukkan ke dalam kategori Strategi Pelandaian Kurva (Flattening the Curve Strategy), yaitu: (a) Peringatan dan Peringatan Dini (Early Warnings and Alerts); (b) Pelacakan dan Prediksi 9 (Tracking and Prediction); dan (c) Dasbor Data (Data Dashboards). Sedangkan yang termasuk Strategi Peningkatan Kemampuan Perawatan Kesehatan (Raising the Health Care SystemStrategy) adalah (a) Diagnosis dan Prognosis; (b) Perawatan dan Penyembuhan (Treatments and Cures); dan (c) Kontrol Sosial (Social Control).

Setelah data teknologi AI dan Big Data diklasifikasikan ke dalam kategori pengembangan IPTEKIN (kategori R, DE, A dan O) dan diklasifikasi kedalam kategori Strategi yang didukungnya(Strategi Penerapan Iptekin melawan COVID-19 (1. Peringatan dan Peringatan Dini, Pelacakan dan Prediksi, Dasbor Data, Diagnosis dan Prognosis, Perawatan dan Penyembuhan,

(C)Asosiasi Prakarsa Indonesia Cerdas (APIC) - 2020 
Kontrol Sosial), maka diperoleh data berikut (Lihat: Tabel 2. Data Strategi Penerapan IPTEKIN di Italia, AS, Tiongkok dan Korseldibawah).

Analisis dilakukan terhadap kecenderungan penerapan salah satu jenis teknologi AI dan Big Data, untuk mendukung pelaksanaan salah satu strategi melawan pandemi COVID-19, dalam hal ini Strategi Pelandaian Kurva atau Strategi Peningkatan Kemampuan Pelayanan Kesehatan.

Dari data di atas, jenis-jenis teknologi AI dan Big Data yang digunakan untuk mendukung pelaksanaan salah satu strategi melawan COVID-19 akan diteliti untuk setiap negara. Informasi yang diperoleh kemudian akan diperbandingkan. Kondisi di mana persamaan-persamaan, maupun perbedaan-perbedaan pilihan teknologi yang digunakan, dengan pilihan strategi melawan pandemi COVID-19 ini kemudian dianalisis.

Untuk kasus negara Italia, dari sembilan (9) jenis Teknologi AI dan Big Data yang sudah pada tahap O (Operational) atau sudah sudah diterapkan, lima (5) jenis teknologi di antaranya digunakan untuk mendukung pelaksanaan Strategi Pelandaian Kurva. Sedangkan empat (4) jenis teknologi di antaranya digunakan untuk mendukung Strategi Peningkatan Kemampuan Pelayanan Kesehatan. Di sini terlihat bahwa jumlah jenis teknologi yang mendukung Strategi Pelandaian Kurva lebih banyak daripada jumlah jenis teknologi yang mendukung Strategi Peningkatan Kemampuan Pelayanan Kesehatan, walaupun dalam kasus Italia, perbedaannya hanya sedikit.

Hal serupa diperoleh dari data jenis teknologi untuk kasus negara Tiongkok dan Korsel. Untuk kasus Tiongkok, dari sembilan (9) jenis teknologi AI dan Big Data yang sudah dalam kategori O atau sudah diterapkan, delapan (8) jenis teknologi di antaranya mendukung pelaksanaan Strategi Pelandaian Kurva. Di sini terlihat bahwa hanya satu di antaranya digunakan untuk mendukung Strategi Peningkatan Kemampuan Pelayanan Kesehatan. Jadi dalam kasus Tiongkok perbedaannya sangat tajam, jauh lebih banyak jenis teknologi yang sudah operasional (diterapkan) yang mendukung Strategi Pelandaian Kurva.

Untuk kasus Korsel juga diperoleh kecenderungan yang sama dengan kasus Tiongkok maupun Italia. Dari 17 jenis teknologi AI dan Big Data yang sudah dalam kategori O atau yang sudah diterapkan, 13 jenis teknologi di antaranya mendukung pelaksanaan Strategi Pelandaian Kurva. Hanya empat (4) jenis teknologi di antaranya digunakan untuk mendukung Strategi Peningkatan Kemampuan Pelayanan Kesehatan. Di sini terlihat lagi bahwa lebih banyak jenis teknologi yang sudah operational (digunakan) yang mendukung Strategi Pelandaian Kurva.

Dengan piranti analisis yang sama dilakukan kajian terhadap AS. Ternyata terdapat perbedaan yang signifikan. Dalam kasus ini, dari sembilan (9) jenis teknologi AI dan Big Data yang sudah diterapkan, lima (5) jenis teknologi di antaranya justru mendukung pelaksanaan Strategi Peningkatan Kemampuan Pelayanan Kesehatan. Sedangkan empat (4) di antaranya digunakan untuk mendukung Strategi Pelandaian Kurva. Jadi tampaklah bahwa pada kasus AS kecenderungannya adalah yang sebaliknya, yaitu lebih banyak jenis teknologi yang sudah operasional (O) (diterapkan) yang mendukung pelaksanaan Strategi Peningkatan Kemampuan Pelayanan Kesehatan.

Apabila dilihat kembali analisis Grafik Jumlah Kasus Terinfeksi baru COVID-19 per hari dan Grafik Total Kasus Terinfeksi virus COVID-19 yang dilaporkan, untuk negara-negara Italia, AS, Tiongkok, dan Korsel, yang sudah dibahas di atas, ditemui bahwa upaya-upaya Containment dan Mitigation, misalnya social distancing, stay at home dan sebagainya (yang merupakan bagian dari Strategi Pelandaian Kurva), telah berhasil mengurangi pertambahan kasus terinfeksi per harinya. Namun, upaya yang terkait Strategi Peningkatan Kemampuan Pelayanan Kesehatan, ternyata masih belum efektif. Ini dapat disimpulkan berdasarkan kenyataan bahwa pertambahan Jumlah Total Kasus Terinfeksi COVID-19 yang cenderung meningkat.

Apabila temuan ini dikaitkan dengan data dan kenyataan mengenai jenis-jenis teknologi AI dan Big Data yang mendukung pelaksanaan Strategi Pelandaian Kurva dan Strategi Peningkatan Kemampuan Pelayanan Kesehatan untuk negara Italia, AS, Tiongkok, dan Korsel di atas, maka perbedaaan negara Tiongkok, Korsel dan Italia dengan AS, dalam pemilihan strategi dan teknologi yang mendukungnya dapat dijelaskan berikut ini. 
Tabel 2 :Data Strategi Penerapan IPTEKIN di Tiongkok, Korsel Italia, AS Diolah [1]

\begin{tabular}{|c|c|c|c|c|c|c|c|c|c|}
\hline \multirow[b]{3}{*}{ No } & \multirow[b]{3}{*}{ STRATEGI PENERAPAN IPTEKIN } & \multicolumn{4}{|c|}{ ITALY } & \multicolumn{4}{|c|}{ USA } \\
\hline & & \multicolumn{2}{|c|}{ TAHAP PENGEMBANGAN } & \multicolumn{2}{|c|}{ CAKUPAN PENERAPAN } & \multicolumn{2}{|c|}{ TAHAP PENGEMBANGAN } & \multicolumn{2}{|c|}{ CAKUPAN PENERAPAN } \\
\hline & & $R, D E, A$ & 0 & NASIONAL & $\begin{array}{l}\text { BEBERAPA } \\
\text { WILAYAH }\end{array}$ & $R, D E, A$ & 0 & NASIONAL & $\begin{array}{c}\text { BEBERAPA } \\
\text { WILAYAH }\end{array}$ \\
\hline 1 & PELAKSANAAN FLATTENING THE CURVE : & & & & & & & & \\
\hline $\mathrm{a}$ & Peringatan \& Peringatan Dini (Early Warnings \& Alerts) & & & & & & & & \\
\hline b & Pelacakan dan Prediksi (Tracking And Prediction) & & 2 & 2 & & & & & \\
\hline c & Dasbor Data (Data Dashboards) & & 1 & 1 & & & 1 & & \\
\hline$d$ & Kontrol Sosial (Social Control) & & 2 & 1 & 1 & 6 & 1 & & 1 \\
\hline 2 & PELAKSANAAN RAISING THE HEATHCARE CAPACITY : & & & & & & & & \\
\hline a & Diagnosis dan Prognosis & 3 & & & & 4 & 2 & & 3 \\
\hline b & Perawatan dan Penyembuhan (Treatments And Cures) & & 4 & 1 & 3 & 8 & 3 & & 2 \\
\hline
\end{tabular}

Tiongkok adalah negara pertama yang terkena infeksi COVID-19. Setelah berkembang di banyak wilayah di negara Tiongkok, maka, di antara 4 negara yang diteliti dalam studi ini, COVID-19 selanjutnya menyebar ke negara-negara Korsel, Italia dan terakhir ke AS [8]. Sebagai negara-negara yang sudah terkena COVID-19 lebih awal, dibandingkan dengan negara AS, maka ketiga negara yang disebut di depan mempunyai kesamaan dalam menerapkan berbagai upaya, kebijakan dan strategi maupun kebijakan penerapan teknologinya. Sesuai data di atas, maka di negara Tiongkok Korsel dan Italia, teknologi AI dan Big Data sudah digunakan dalam mendukung pelaksanaan Strategi Pelandaian Kurva. Sedangkan untuk pelaksanaan Strategi Peningkatan Kemampuan Pelayanan Kesehatan, teknologi yang dipergunakan relatif belum banyak.

Menurut Anderson [9], memang langkah pertama dalam menghadapi pandemi COVID-19 adalah menerapkan upaya Pelandaian Kurva, yang mencakup upaya Containment dan Mitigation seperti social distancing, stay at home, mencuci tangan dan sebagainya secara luas dan konsisten.

Namun oleh karena pesatnya perkembangan pandemi COVID-19 dan cepatnya pertambahan jumlah kasus terinfeksi per harinya, maka dirasakan bahwa pelaksanaan Containment dan Attainment perlu segera didukung iptekin yang sesuai Wang [10]. Ini merupakan alasan mengapa di negara Tiongkok, Korsel, dan Italia, lebih banyak teknologi yang mendukung Strategi Pelandaian Kurva. Untuk Strategi Peningkatan Kemampuan Pelayanan Kesehatan, teknologi AI dan Big Data yang mendukungnya belum banyak, walaupun mulai mendapat perhatian dan minat [11].

Untuk kasus negara AS, kondisi penerapan teknologinya berbeda, yang ditemui adalah justru sebaliknya. Di sini, lebih banyak jenis teknologi yang sudah operasional (diterapkan) yang digunakan untuk mendukung pelaksanaan Strategi Peningkatan Kemampuan Pelayanan Kesehatan.

Mengapa demikian? Hal ini dapat dijelaskan sebagai berikut. Italia, Tiongkok dan Korsel menerapkan Strategi Pelandaian Kurva sejak awal pandemi COVID-19 berkembang. Dengan dukungan teknologi AI, maka strategi tersebut dirasakan efektif dalam menurunkan jumlah kasus terinfeksi COVID-19 per harinya. Sejalan dengan terus berkembannya pandemi, negara-negara tersebut juga menambah jenis teknologi yang diterapkan untuk mendukung Strategi Pelandaian Kurva pada saat itu (Thunstrom, L et.al., 2020). Dengan terus bertambahnya jumlah total kasus terinfeksi COVID-19 di negara Tiongkok, Korsel, dan Italia, maka strategi berikutnya, yaitu Strategi Peningkatan Kemampuan Pelayanan Kesehatan mulai diimplementasikan, dan teknologi AI dan Big Data yang dapat mendukungnya juga diterapkan [6].

Dalam kasus negara AS, berbeda. AS sangat terlambat di dalam mengambil langkah-langkah untuk melawan pandemi COVID-19. Pada awal implementasi kebijakan Strategi Pelandaian Kurva, AS mengandalkan komunikasi yang lebih konvensional, melalui berbagai bentuk media massa untuk mendorong pelaksanaan social distancing dan lain-lain. Karena banyaknya pemberitaan media mengenai jumlah kasus yang terinfeksi dan meninggal dunia, maka masyarakat kemudian baru merespon dengan mematuhi kepada upaya Containment and Mitigation. Namun ketika jumlah kasus terinfeksi COVID-19 per harinya terus meningkat dan kapasitas sumberdaya kesehatan terlihat mulai menemui kesulitan menanganinya, maka teknologi AI dan Big Data yang mendukung Strategi Peningkatan Kemampuan Perawatan Kesehatan diterapkan. 


\section{Pengembangan IPTEKIN oleh TFRIC-19 BPPT}

Di Indonesia, Badan Pengkajian dan Penerapan Teknologi (BPPT) mendapat kepercayaan dari Kementerian Riset dan Teknologi (Kemenristek/BRIN) sebagai koordinator percepatan pengembangan produk dalam negeri untuk mengatasi pandemi COVID-19. Melalui sinergi kelembagaan bertajukTask Force Riset dan Inovasi Teknologi untuk Penanganan COVID-19 (TFRIC-19) telah dihasilkan berbagai produk buatan dalam negeri antara lain dengan mengembangkan lima (5) produk utama yang tertuang dalam rencana aksi cepat berikut: (1) Non-PCR DiagnosticTest COVID-19 (dalam bentuk dip stick dan micro-chip); (2) PCR Test Kit, Laboratorium Uji PCR dan Sequencing; (3) Sistem Informasi dan Aplikasi Kecerdasan Buatan (Artificial Intelligence/AI); (4) Analisis dan Penyusunan Data Whole Genome COVID-19 Origin Orang Indonesia yang Terinfeksi; dan (5) Penyiagaan Sarana dan Prasarana Deteksi, Penyediaan Logistik Kesehatan dan Ekosistem Inovasi dalam Menangani Pandemi COVID-19.

Presiden RI Joko Widodo pada acara Kebangkitan Inovasi Indonesia, 20 Mei 2020 meluncurkan produk inovasi penanganan COVID-19, di antaranya RDT Kit, PCR Test Kit, Artificial Intelligence untuk mendeteksi COVID-19, Mobile Lab Bio Safety Level 2, dan Emergency Ventilator yang merupakan inovasi BPPT bersama TFRIC-19.

Apabila data mengenai Pengembangan Iptekin yang telah dilakukan oleh TPRIC-19 BPPT diteliti, maka jenis-jenis produk untuk melawan COVID-19 yang telah dihasilkan adalah:

a. RDT Kit IgG IgM Non PCR (RI-GHA COVID-19) (dalam bentuk dip stick dan micro-chip).

b. PCR Test Kit (BIOCOV-19).

c. Mobile Lab BSL-2 untuk swab test.

d. Alat Kesehatan:

○ Emergency Ventilator,

- Face Shield,

- Mobile Handwasher.

Adapun Data Tahapan Pengembangan dan Cakupan Penerapan produk-produk ini dapat dilihat pada Tabel 3. Data Strategi Penerapan Iptekin oleh TFRIC-19 BPPT berikut:

\begin{tabular}{|c|c|c|c|c|c|}
\hline \multirow[b]{3}{*}{ No } & \multirow[b]{3}{*}{ STRATEGI PENERAPAN IPTEKIN } & \multicolumn{4}{|c|}{ TFRIC-19 BPPT } \\
\hline & & \multicolumn{2}{|c|}{ TAHAP PENGEMBANGAN } & \multicolumn{2}{|c|}{ CAKUPAN PENERAPAN } \\
\hline & & $R, D E, A$ & 0 & NASIONAL & $\begin{array}{l}\text { BEBERAPA } \\
\text { WILAYAH }\end{array}$ \\
\hline 1 & PELAKSANAAN FLATTENING THE CURVE: & & & & \\
\hline a & Peringatan \& Peringatan Dini (Early Warnings \& Alerts) & & & & \\
\hline b & Pelacakan dan Prediksi (Tracking And Prediction) & 2 & 1 & & 1 \\
\hline c & Dasbor Data (Data Dashboards) & & & & \\
\hline d & Kontrol Sosial (Social Control) & 1 & & & \\
\hline 2 & PELAKSANAAN RAISING THE HEATHCARE CAPACITY : & & & & \\
\hline a & Diagnosis dan Prognosis & 1 & & & \\
\hline b & Perawatan dan Penyembuhan (Treatments And Cures) & 1 & & & \\
\hline
\end{tabular}

Dari Tabel 3 data diatas tampak bahwa dari lima (5) jenis produk teknologi yang sudah diproduksi oleh TFRIC-19 BPPT, terlihat bahwa tiga (3) produk diarahkan untk mendukung Strategi Pelandaian Kurva (Flattening the Curve Strategy), sedangkan dua (2) produk lainnya diarahkan untuk mendukung Strategi Peningkatan Kemampuan Perawatan Kesehatan (Raising the Health Care Capacity Strategy).

Efektivitas suatu strategi melawan pandemi COVID-19 sangat tergantung pada dukungan iptekin yang digunakan, yang dapat memastikan cakupan, kecepatan dan ketepatan penerapan teknologi dalam melawan pandemi COVID-19 tersebut dalam hal tracing, testing dan treatment. Hal ini dapat dicapai dengan penggunaan Kecerdasan Buatan (Artificial Intellegence/AI), Big Data dan Teknologi Informasi dan Komunikasi (ICT).

(C)Asosiasi Prakarsa Indonesia Cerdas (APIC) - 2020 
Namun dalam kasus TFRIC-19 BPPT, barusatu produk yang sudah dalam tahap operasional, yaitu RDT Kit IgG IgM Non PCR, yang cakupan penerapannya di kota-kota di Yogyakarta, Semarang dan Solo sebanyak 10.000 Test Kit. Sedangkan produk-produk TFRIC-19 BPPT yang lain, masih dalam tahap Available (A), dan belum dioperasionalkan.

Dari kelima(5) produk TFRIC-19 BPPT, satu produk diantaranya dirancang dengan menggunakan Teknologi Artificial Intellengence (AI), namun belum menggunakan ICT maupun Big Data, yaitu CT Scan Berbasis AI (Machine Learning, Deep Learning, Data Mining Platform, Knowledge Growing System).

Dengan berjalannya waktu TFRIC-19 BPPT terus berkembang melalui dinamika berbagai proses inovasi agar implementasi strategi melawan pandemi COVID-19 dapatlebih efektif.

\section{Penutup}

\section{A. Kesimpulan}

Dari kajian dan analisis tentang Tiongkok dapat disimpulkan bahwa negara ini menunjukkan pemanfaatan beragam cara dan teknologi. Di dalam menanggulangi dan mencegah terjadinya penularan COVID-19, ditetapkan kebijakan lock down, diikuti dengan penerapan rekayasa sosial (social engineering) dengan menjaga jarak, penggunaan masker wajah, berjemur matahari, tidak bersentuhan satu sama lain, selain dimanfaatkannya teknologi penggunaan tracker, Kode QR kesehatan di Hangzhou. Hangzhou adalah salah satu kota pertama yang menggunakan Big Data dan IT dalam pencegahan dan pengendalian COVID-19. Mereka menamakan pendekatan itu "satu peta, satu kode QR, dan satu indeks." Kode QR kesehatan dibuat untuk semua orang di kota dan semua orang yang memasuki kota. Sistem pengawasan kesehatan ini telah diterapkan pada sebagian besar kota di Provinsi Zhejiang dan provinsi lain di Tiongkok.

Dari kajian tentang Korsel, dapat disimpulkan bahwa produk IPTEKIN yang didominasi oleh ICT dan diciptakan oleh berbagai lembaga terbukti efektif dalam mendukung penanggulangan kasus COVID-19. Kehebatan produk ICT terbagi tiga kelompok besar yaitu pencegahan, proses dan pelacakan dan pengobatan mampu menurunkan angka kasus, memberikan percepatan pada penurunan dan penyembuhan pasien COVID-19. Keberhasilan produk iptekin ini tidak terlepas dari peran dan koordinasi antarlembaga baik swasta, pemerintah maupun universitas. Kebijakan yang tepat sasaran memungkinkan kerjasama ketiganya dapat mempercepat penciptaan produk.

Dari kajian tentang Italia dapat disimpulkan bahwa kebijakan iptekin di negara ini dalam mengatasi pandemi COVID-19 dapat dibagi ke dalam dua fase, yaitu fase sebelum seruan "Innova per l'Italia" dan setelah seruan "Innova per l'Italia".Kebijakan iptekin digagas oleh lintas kementerian Italia. Seruan ini ditujukan kepada perusahaan, universitas, badan dan pusat penelitian publik dan swasta, asosiasi, koperasi, konsorsium, yayasan dan lembaga untuk memberikan kontribusi di bidang perangkat untuk pencegahan, diagnostik, dan pemantauan untuk penahanan dan pengendalian penyebaran SARS-CoV-2 di seluruh Italia.Penerapan kebijakan tersebut dilakukan melalui penerapan sembilan (9) jenis teknologi, yaitu Blockchain Apps, Open-source technologies, Nanotechnologies, 3D Printing, Drones, Artificial intelligence, Telehealth Technologies, Robots, dan Big Data (Analytics \& Cognitive Systems). Selain itu, upaya dalam menangani COVID-19 dibagi ke dalam dua kategori yaitu pemantauan, pengawasan, deteksi dan pencegahan COVID-19 (yang berhubungan langsung dengan COVID-19) dan mitigasi dari dampak COVID-19 (yang tidak secara langsung berhubungan dengan COVID-19).

Dari kajian tentang Amerika Serikat dapat disimpulkan bahwa teknologi AI dan Big Data, jika sudah diterapkan (klasifikasi Operational-O), keandalannya teruji. Dengan berjalannya waktu pemanfaatan AI tersebut digunakan di banyak Negara Bagian. Penerapan AI dan Big Data, walaupun sudah banyak diterapkan, khususnya dalam kaitan dengan upaya Peningkatan Kemampuan Pelayanan Kesehatan, AS masih mengandalkan upaya-upaya Containment dan Mitigation yang konvensional, dengan menerapkan peraturan dan melakukan sosialisai kepada masyarakat. Seberapa besar peran AI dan Big Data dalam kontribusi melawan COVID-19 di AS tidak dapat diungkapkan. Hal ini menyebabkan kajian Penerapan Iptekin di AS saat ini tidak mungkin memberi penilaian mengenai efektivitas penerapan Iptekin dalam melawan COVID-19. 
Dalam penerapan strategi melawan COVID-19, dari kasus keempat negara yang diteliti, kesemuanya cenderung memperoleh keberhasilan di dalam menerapkan Strategi Pelandaian Kurva. Ini ditandai dengan Grafik Jumlah Penambahan Kasus Positif COVID-19 per hari keempat negara yang menurun. Namun, dalam menerapkan Strategi Peningkatan Kemampuan Perawatan Kesehatan, keempat negara ini masih perlu diperbaiki. Ini terlihat dari kenyataan bahwa pertambahan Jumlah Total Kasus Terinfeksi COVID-19 masih meningkat.

Untuk mendukung kebijakan, maka penerapaniptekin di Tiongkok, Korsel dan Italia lebih banyak mendukung Strategi Pelandaian Kurva. Sedangkan untuk di AS sebaliknya, iptekin yang diterapkan lebih banyak mendukung Strategi Peningkatan Kemampuan Perawatan Kesehatan. Ini karena negara Tiongkok, Korsel dan Italia lebih dahulu terkena infeksi COVID-19. Negara-negara ini langsung menerapkan Strategi Pelandaian Kurva yang kemudian diikuti dengan penerapan iptekin terkait. Di lain pihak, AS mengalami keterlambatan dalam melakukan respon terhadap pandemi COVID-19. Cepatnya pertambahan jumlah kasus terinfeksi COVID-19 menyebabkan AS langsung berupaya menerapkan Strategi Peningkatan Kemampuan Perawatan Kesehatan.

Akhirnya, secara keseluruhan, meskipun fokus analisis kajian ini adalah pada aplikasi teknologi yang menghadirkan solusi untuk menekan masalah terkait pandemi, kajian ini tidak bertujuan untuk menafikan peran faktor lain seperti partisipasi masyarakat di dalam mematuhi berbagai kebijakan yang sudah ditetapkan. Peran iptekin tidak dapat menggantikan atau menebus langkah-langkah kebijakan publik lainnya atau tidak dapat dimainkan di dalam menyelesaikan tantangan sosial yang kompleks sekiranya dilepas tersendiri tanpa bantuan peran yang lain. Dengan kata lain, aplikasi teknologi bagaimanapun canggih dan majunya tetap merupakan instrumen penting yang bersifat mendukung. Dan menjadi semakin penting dalam merespon kondisi darurat di dalam waktu yang sangat pendek sebagaimana pandemi COVID-19.

\section{B. Pembelajaran}

Pembelajaran dari Tiongkok terutama adalah bahwa kerjasama dengan raksasa teknologi. Sebagai episentrum pertama, Tiongkok telah mengembangkan dan memanfaatkan teknologi sebagai garda depan perang melawan pandemi COVID-19. Pengembangan teknologi-teknologi tersebut tidak terlepas dari peran berbagai perusahaan teknologi swasta raksasa yang pada umumnya telah memiliki Big Data dan AI dengan berbagai algoritma yang membuat kegiatan tracing, tracking, positioningdanscreening menjadi lebih mudah. Selain itu, bekerja cerdas dalam mengembangkan teknologi pengawasan (surveillance), pemanfaatan media sosial online seperti WeChat dan Baidu. Robot dimanfaatkan terutama di rumah sakit untuk mengurangi resiko terpaparnya tenaga medis dari pasien positif COVID-19. Drone juga dimanfaatkan dalam berbagai pengangkutan sampel dan peralatan medis, penyemprotan disinfektan ke desa-desa hingga screening suatu daerah. Kontak fisik antara tenaga kemanusiaan penanggulangan COVID-19 dan para pasien COVID-19 dapat diminimalisasi.Berbagai kebijakan pemanfaatan teknologi yang diambil oleh Pemerintah juga disertai dengan ketegasan(law enforcement).

Pembelajaran dari Korsel terutama adalah penciptaan koordinasi yang sinergis antara lembaga terkait Pemerintah, Swasta, Universitas dan parisipasi masyarakat dalam penciptaan produk iptek yang mampu mendukung kebijakan penurunan kasus COVID 19. Dukungan pemerintah pusat dan daerah berupa kebijakan penggunaan produk iptek buatan dalam negeri sangat mendorong kerjasama antara swasta/industri dan lembaga penelitian dalam pembuatan produk. Selain itu, promosi pemerintah terhadap produk ICT tertentu untuk mendukung suatu kebijakan sangat membantu dalam pembentukan pasar yang pada akhirnya memberikan keuntungan bagi swasta/industri dalam negeri.

Pembelajaran dari Italia terutama adalah dalam pemanfaatan teknologi blockchain di Italia dalam konteks pemanfaatan aplikasi bitcoin fundraiser cukup baik, mengingat kebutuhan akan peralatan medis saat pandemi sangat tinggi terlebih pasokan dirasakan kurang. Dengan teknologi blockchain, sistem pengumpulan hingga distribusi baik dari penggalangan dana, pemesanan produk, pengiriman bahkan hingga penyaluran peralatan medis dapat dilakukan dengan cepat, tepat, dan transparan. Selain itu, biaya operasional menjadi minimal karena dapat memangkas jalur birokrasi.

Pembelajaran dari Amerika Serikat terutama adalah bahwa AI dan Big data dapat memegang peran kunci dalam memerangi pandemi COVID-19 melalui berbagai aplikasi, mulai dari pelacakan wabah, deteksi virus hingga pengobatan dan dukungan diagnosis. Di satu sisi, AI mampu menyediakan solusi yang layak untuk memerangi pandemi COVID-19 dengan beberapa cara. AI dan

CAsosiasi Prakarsa Indonesia Cerdas (APIC) - 2020 
Big Data dapat mendukung prediksi wabah, deteksi coronavirus juga sebagai infodemiologi dan infoveillance dengan memanfaatkan pembelajaran berbasis teknik seperti ML dan DL dari pemodelan COVID-19-centric, klasifikasi, dan estimasi. Apalagi AI sudah muncul sebagai alat yang menarik untuk memfasilitasi vaksin dan obat-obatan manufaktur. Dengan menggunakan dataset yang disediakan oleh layanan kesehatan organisasi, pemerintah, laboratorium klinis dan pasien, AI memanfaatkan alat analitik cerdas untuk memprediksi yang efektif dan vaksin/obat yang aman terhadap COVID-19, yang mungkin menguntungkan dari perspektif ekonomi dan ilmiah. Di lain pihak, Big Data kemampuannya berpotensi untuk mengatasi pandemi COVID-19. Big Data berpotensi menyediakan berbagai solusi yang menjanjikan untuk membantu melawan pendemi COVID-19. Dengan menggabungkan dengan kemampuan analitik AI, Big Data dapat membantu untuk memahami COVID-19 dalam hal struktur virus tersebut dan perkembangan penyakitnya. Big Data dapat membantu penyedia layanan kesehatan dalam berbagai operasi medis dari diagnosa awal penyakit dan analisis terhadap prediksi hasil pengobatan. Integrasi AI dan Big Data dapat menjadi kunci memampukan Pemerintah dalam memerangi potensi COVID-19.

Indonesia dengan berbagai capaiannya, meski agak terlambat, tampak sudah mulai dengan langkah-langkah nyata dalam menyiapkan upaya melawan COVID-19. Pendekatan TFRIC-19 BPPT adalah menghadirkan ekosistem riset dan inovasi teknologi yang bertujuan untuk menghasilkan pendekatan holistik sebagai upaya mengatasi masalah pandemi secara terstruktur dan sistematik. Konsep dasar penanganan wabah virus secara epidemiologi yang mengedepankan mekanisme testing, tracing, fencing atau isolating, dan treatment direspon dengan membangun jejaring riset yang diharapkan mampu menghasilkan produk hilir mandiri yang langsung dapat menjadi solusi.Pendekatan dengan konsep membangun ekosistem ini pada hakikatnya bukan hanya berorientasi pada target pengentasan wabah saja, melainkan juga sebagai upaya untuk memperbaiki pengelolaan potensi riset dan inovasi teknologi Indonesia di masa yang akan datang.

\section{ACKNOWLEDGEMENT}

Penulis mengucapkan terima kasih kepada Tim Kajian Kebijakan Penanggulangan COVID-19 Luar Negeri - Pusat Teknologi Kawasan Spesifik dan Sistem Inovasi, BPPT yang telah membantu pengumpulan data-data selama masa Work From Home (WFH).

\section{REFERENSI}

[1] Tim PTKSSI, BPPT, "Kajian COVID-19: Pembelajaran dari Korea Selatan, Italia, Tiongkok, dan Amerika", April 2020.

[2] Xifeng $\mathrm{Wu}$, Xiaolin $\mathrm{Xu}$, Xuchu Wang.“6 lessons from China's Zhejiang Province and Hangzhou on how countries can prevent and rebound from an epidemic like COVID19".https://www.weforum.org/agenda/2020/03/coronavirus-covid-19-hangzhou-zhejianggovernment-response/, 2020

[3] M. Kritikos, "Ten technologies to fight coronavirus, the Scientific Foresight Unit within the Directorate-General for Parliamentary Research Services (EPRS) of the Secretariat of the European Parliament", April 2020.

[4] Various Data, Centers for Disease Control and Prevention (CDC) .https://www.cdc.gov/coronavirus/2019-ncov/index.html.

[5] Linda Thunström, S. C. Newbold, D. Finnoff, M.Ashworth "The benefits and costs of using social distancing to flatten the curve for COVID-19", April 2020.

[6] B. Armocida, B. Formenti, S. Ussai, F. Palestra. "The Italian health system and the COVID19 challenge",2020.

[7] R.P. Walensky and C. J. J. del Rio. "From Mitigation to Containment of the COVID-19 Pandemic: Putting the SARS-CoV-2 Genie Back in the Bottle. JAMA, https://jamanetwork.com., May, 2020.

[8] WHO, "Novel Coronavirus ( 2019-nCoV): Situation Report, 3.", 2020 
[9] R. M. Anderson, R. M., H Heesterbeek, D Klinkenberg. "How will country-based mitigation measures influence the course of the COVID-19 epidemic?" The Lancet 395(10228): 931934, https://thelancet.com, 2020.

[10] J. Wang."Response to COVID-19 in Taiwan: Big Data Analytics, New Technology, and Proactive Testing". JAMA, https://jamanetwork.com., 2020.

[11] WHO, "Coronavirus disease 2019 ( COVID-19): Situation Report, 53.", 2020 